Japan. J. Med. Sci. Biol., 25, 85-93, 1972

\title{
THE EFFECT OF AN IRON DRUG ON THE GROWTH OF PLAGUE MICROORGANSIMS IN VITRO AND IN GUINEA PIG SKIN
}

\author{
HiRoKo TSUKANO, MAKOTO YAMAMOTO AND AKIRA WAKE \\ The 1st Department of Bacteriology, National Institute of \\ Health, Tokyo 141, Japan
}

(Received: October 13, 1971)

\begin{abstract}
SUMMARY : The effects of iron on the growth of plague microorganisms were examined with broth and agar media of deironized brain heart infusion added with or without chondroitin sulfate ferric chloride. The iron-deficiency inhibited growth-initiation of $\mathrm{P}^{-}$attenuated vaccine strain EV of Yersinia pestis, but affected slightly the generation time in the later growth. Such a high dose as $3 \mathrm{mg} \mathrm{Fe} / \mathrm{ml}$ was, however, inhibitory to the strain. The substrains selected from the colonies grown on an iron-deficient medium acquired a partial tolerance to such environmental condition. Hyperimmune antiplague rabbit serum inhibited the growth of EV microorganisms, which was removed by addition of more than $0.5 \mathrm{mg} \mathrm{Fe} / \mathrm{ml}$ of the iron drug. Four $\mathrm{mg} \mathrm{Fe} / \mathrm{ml}$ was still a growth-stimulating concentration in the HAPS- containing environment.

When EV microorganisms were introduced into guinea pig skin together with $0.1 \mathrm{ml}$ of the iron drug containing $0.4 \mathrm{mg} \mathrm{Fe}$, viable counts increased from $10^{4}$ to $10^{7}$ within 2 days and the same level persisted at least for 1 week.
\end{abstract}

\section{INTRODUCTION}

In the preceding paper (Wake, Morita and Yamamoto, 1972) an apparent virulence-enhancing effect of chondroitin sulfate ferric iron on plague microorganisms was demonstrated in two systems of animal experiments : non-immune mice administered intraperitoneally with the iron drug were killed by challenge with $\mathrm{P}^{-}$ attenuated plague vaccine strain $\mathrm{EV}$, and immune mice treated in the same way were not protected themselves against infection. From the histopathological findings, the phenomenon was interpreted as a result of possible interference with the host defense mechanism by the drug.

The present paper is to show the direct effect of iron on plague microorganisms in deironized brain heart infusion and also in hyperimmune antiplague rabbit serum. In addition, a time-course observation was presented of the fate of the EV strain injected with the iron drug into the guinea pig skin.

\section{MATERIALS AND METHODS}

Bacteria, medium and iron drug: These were described in the preceding paper (Wake, Morita and Yamamoto, 1972).

Deironized medium: Three hundred and seventy grams of Brain Heart Infusion (BHI, Difco) was dissolved in 1 liter of distilled water. This was deironized by

塚野尋子・山本 実・和気 朗（国立予防衛生研究所細菌第一部） 
calcium phosphate gel adsorption to contain less than $0.1 \mu \mathrm{g}$ of the metal per $\mathrm{ml}$. The deironized broth (DBHIB) was prepared by 1: 10 dilution of this solution in redistilled water. To prepare iron-containing broth, an appropriate dilution of Blutal $(4 \mathrm{mg} \mathrm{Fe} / \mathrm{ml})$ was used instead of simple redistilled water. Oxoid Agar No. 1 (Oxoid, $1 \%)$ was used to solidify DBHIB into agar medium (DBHIA).

Hyperimmune antiplague rabbit serum (HAPS): A rabbit was hyperimmunized by repeated subcutaneous and intravenous injections with living A1122 strain. The serum collected 2 to 3 months after termination of immunization showed an agglutination titer of 1: 2048 against the strain.

Guinea pigs: They were maintained in the same way as described in the preceding paper (Wake, Morita and Yamamoto, 1972).

Viable counts: For enumeration of viable plague microorganisms in liquid media, $0.1 \mathrm{ml}$ of appropriate dilutions was spread over BHI agar plates, and the number of colonies were counted after a 3-day incubation at $27 \mathrm{C}$, unless otherwise described. Usually, 3 to 5 plates were employed for each dilution, and the resulted colony counts were averaged. For enumeration of viable microorganisms in guinea pig skin, the ressected piece of the skin was carefully homogenized in a Potter tube containing $2 \mathrm{ml}$ of sterile saline added with $1 \%$ bovine serum albumin (BSA, Armour), and the homogenate was inoculated onto the agar plates.

Precautions against iron contamination: Pyrex glass vessels or plastic disposable plates (Zintan Thermo) were used. The water used for any purpose was redistilled. Before sterilization, all glass apparatus was soaked for at least $24 \mathrm{hr}$ in a diluted solution of ethylenediamine-tetra-acetic acid $(0.1 \mathrm{~g}$ of the sodium salt dissolved in 1 liter of water) and then throughly rinsed with redistilled water.

\section{RESULTS}

\section{Growth of EV in DBHIB with or without Iron Drug}

DBHIB was dispensed into 8 series of screw-cap tubes by $10 \mathrm{ml}$, with or without the iron drug (Blutal) in concentrations of $0.0004 \mathrm{mg}, 0.004 \mathrm{mg}, 0.4 \mathrm{mg}, 1.2 \mathrm{mg}, 2.0 \mathrm{mg}$ and $3.0 \mathrm{mg} \mathrm{Fe} / \mathrm{ml}$, respectively. These tubes were inoculated with $0.1 \mathrm{ml}$ of a washed EV suspension of a 2-day culture on BHIA slants in iron-free saline. At the same time, viable bacilli contained in this inoculum were enumerated. Then, a time-course enumeration of viable $\mathrm{EV}$ microorganisms was made on samples taken from each $\mathrm{Fe}$ concentration series after 1,2, 3, 4, 7, 10 and 14 days of incubation at $37 \mathrm{C}$. Figure one shows the results.

Though variation in viable count within one log could not be taken as significant because of the technical limitations involved in plate counting, the growth and survival of $\mathrm{EV}$ microorganisms were nearly the same in this environment irrespective of the iron concentration. However, the medium of $0.0004 \mathrm{mg} \mathrm{Fe} / \mathrm{ml}$ gave an exceptionally low count on the $3 \mathrm{rd}$ day (Curve 2), and viable counts in the medium of $3.0 \mathrm{mg} \mathrm{Fe} / \mathrm{ml}$ decreased abruptly after the 4 th day (Curve 8). It appeared paradoxical that Curve 2 was lower than Curve 1 (iron-deficiency) on the $3 \mathrm{rd}$ day. Such apparently irregular results will be discussed later.

\section{Colony Formation of EV on DBHIA Plates}

An iron-free saline suspension of $\mathrm{EV}$ was prepared in the concentration of $1 \mathrm{mg}$ 
TABLE I

Colony formation of EV microorganisms on DBHIA with or without the iron drug

\begin{tabular}{ccccc}
\hline & \multicolumn{5}{c}{ Number of visible colonies on } \\
\cline { 2 - 5 } & \multicolumn{2}{c}{ Fe-free medium } & Fe-containing medium \\
\hline inoculum & $\begin{array}{l}0.1 \mathrm{ml} \\
10^{-4}\end{array}$ & $\begin{array}{l}0.1 \mathrm{ml} \\
10^{-5}\end{array}$ & $\begin{array}{l}0.1 \mathrm{ml} \\
10^{-4}\end{array}$ & $\begin{array}{l}0.1 \mathrm{ml} \\
10^{-5}\end{array}$ \\
\hline days & & & & \\
\hline 1 & 3 & 1 & 33 & 6 \\
\hline 2 & 11 & 3 & n. d. ${ }^{* * *}$ & 741 \\
\hline 3 & 23 & 5 & n. d. ${ }^{* * *}$ & 1582 \\
\hline 5 & 203 & 9 & n. d. ${ }^{* * *}$ & 1666 \\
\hline & n. d. ${ }^{* *}$ & 26 & n. d. ${ }^{* * *}$ & 1678 \\
\hline
\end{tabular}

* The concentration of the iron drug was $0.4 \mathrm{mg} \mathrm{Fe} / \mathrm{ml}$.

** Accurate counting was impossible, because of the satellite colony formation.

*** The number of colonies were innumerable.

TABLE II

Colony formation of EV microorganisms grown on an iron-deficient medium on DBHIA with or without the iron drug

\begin{tabular}{ccc}
\hline & \multicolumn{2}{c}{ Number of visible colonies on } \\
\cline { 2 - 3 } & Fe-free medium & Fe-containing medium \\
\hline inoculum & $\begin{array}{c}0.1 \mathrm{ml} \\
10^{-5}\end{array}$ & $\begin{array}{l}0.1 \mathrm{ml} \\
10^{-5}\end{array}$ \\
\hline days & 0 & 0 \\
\hline 1 & 98 & 301 \\
\hline 3 & 184 & 601 \\
\hline 4 & 194 & 612 \\
\hline 5 & 204 & 619 \\
\hline
\end{tabular}

* The concentration of the iron drug was the same as Table I.

wet bacilli per $\mathrm{ml}$. Both $10^{-4}$ and $10^{-5}$ dilutions of this suspension were spread in an amount of $0.1 \mathrm{ml}$ onto 10 plates of DBHIA with or without the iron drug in 0.4 $\mathrm{mg} \mathrm{Fe} / \mathrm{ml}$. Thus, a total of 40 plates inoculated were incubated at $27 \mathrm{C}$; counting was made daily for the next 5 days. The results are summariezd in Table I. The 

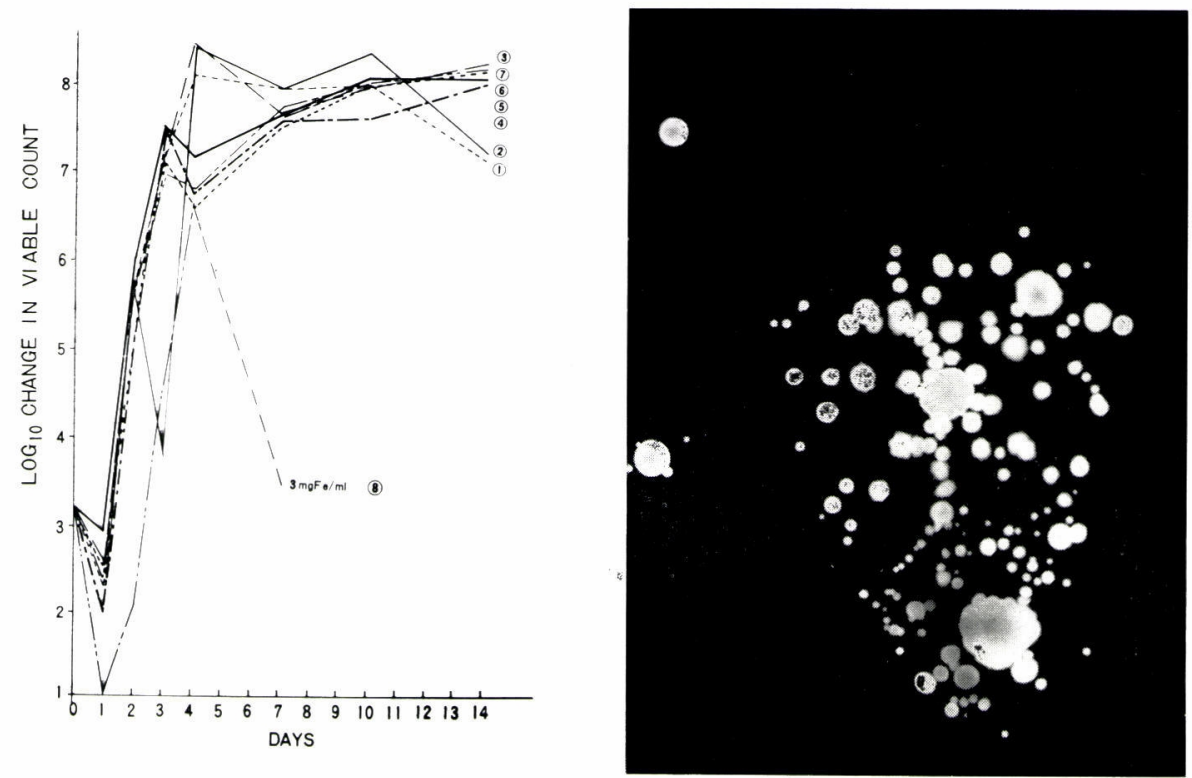

Fig. 1. Growth and survival of EV in DBHIB and DBHIB added with known doses of iron drug.

(1) DBHIB, Fe free, (2) - (8) DBHIB plus the iron drug. The concentrations in $\mathrm{Fe}$ equivalent were: (2) $0.0004 \mathrm{mg} / \mathrm{ml}$; (3) $0.004 \mathrm{mg} / \mathrm{ml}$; (4) $0.04 \mathrm{mg} / \mathrm{ml}$; (5) $0.4 \mathrm{mg} / \mathrm{ml}$; (6) 1.2 $\mathrm{mg} / \mathrm{ml}$; (7) $2.0 \mathrm{mg} / \mathrm{ml}$; (8) $3.0 \mathrm{mg} / \mathrm{ml}$.

Fig. 2. Satellite colonies on DBHIA plates spread with thousands of EV microorganisms. The central larger colonies may have initated the growth of nearby microorganisms.

table may indicate two facts: (1) only $1.6 \%$ of EV microorganisms in the inoculum initiated the growth on the iron-deficient medium on the assumption that the total population could have grown on iron-containing plates, and (2) the number of new colonies on the iron-deficient plates increased gradually day after day indicating delayed initiation of growth in this environment.

Three independent colonies on an iron-deficient plate were scraped off and suspended in iron-free saline. With $10^{-5}$ dilution of this suspension the same experiment as above was repeated. This time, 12 DBHIA plates were employed for each medium with or without the iron drug. The results are shown in Table II. This time, the plating efficiency of the selected substrain increased up to $33.0 \%$. On the iron-containing medium the ratio of viable counts on each day to that on the 5 th day were similar; for example $44.1 \%$ and $48.6 \%$ on the 2 nd day and $94.2 \%$ and $97.1 \%$ on the $3 \mathrm{rd}$ day. Another interesting phenomenon was that many satellite colonies developed on the iron-deficient medium when thousands of viable microorganisms were spread (Fig. 2). Discussion will be made on this phenomenon later.

\section{Growth and Survival of EV in HAPS}

HAPS was dispensed into 8 sterilized ampoules in the amount of $2 \mathrm{ml}$ and lyophilized. They were reconstituted in $2 \mathrm{ml}$ of serial dilutions of the iron drug so 
that each would contain $0,0.0001 \mathrm{mg}, 0.001 \mathrm{mg}, 0.01 \mathrm{mg}, 0.1 \mathrm{mg}, 0.5 \mathrm{mg}, 1 \mathrm{mg}, 2 \mathrm{mg}$ or $4 \mathrm{mg} \mathrm{Fe}$ per $\mathrm{ml}$. They were inoculated with $\mathrm{EV}$ microorganisms in the similar way as the preceding experiments. Enumeration of viable bacilli was conducted with $0.1 \mathrm{ml}$ aliquots from each tube in $0,2,3,4,7,10$ and 14 days of incubation at 37C. The results are shown in Fig. 3. Viable counts decreased markedly with iron of 0.1 $\mathrm{mg} / \mathrm{ml}$ or less. On the contrary, viable counts increased rapidly in response to the iron concentration of $0.5 \mathrm{mg} / \mathrm{ml}$ or higher.
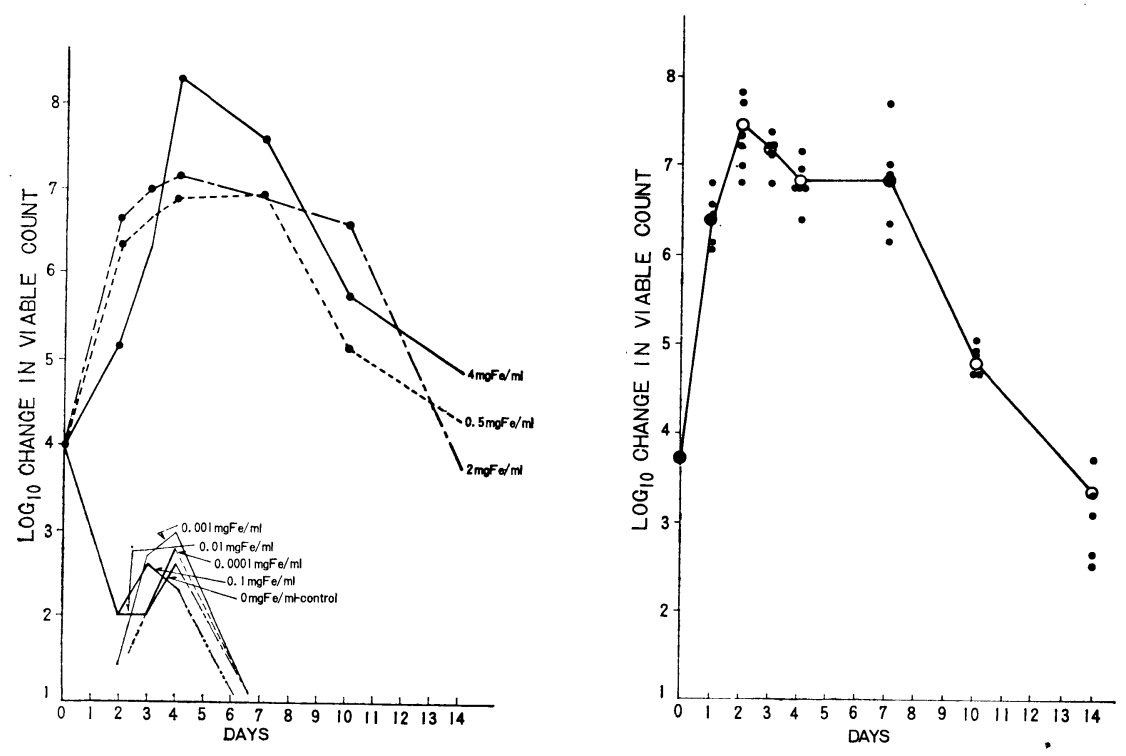

Fig. 3. Growth and survival of EV in HAPS at $37 \mathrm{C}$.

Fig. 4. Growth and survival of EV injected into the guinea pig skin together with the iron drug. The concentration of the iron drug was equivalent to $4 \mathrm{mg} F \mathrm{Fe}$ per ml.

\section{Growth and Survival of EV Microorganisms Inoculated with the Iron Drug into Guinea Pig Skin}

Forty-two guinea pigs were infected intracutaneously on the back with $0.2 \mathrm{ml}$ of a suspension of EV microorganisms. The inoculum was prepared by suspending a 2 day culture of the strain in the iron drug solution. Its original viability was examined before use. In $1,2,3,4,7,10$, and 14 day after infection, the infected skin areas of 5 to 6 animals were cut out aseptically. The viable EV microorganisms of the homogenates of the removed skin were counted. Special care was taken to cover the entire infection area and to ensure complete homogenization of skin. The results are shown in Fig. 4. The strain multiplied markedly showing increased viable counts by $4 \mathrm{log}$ levels for the first 2 weeks, and then persisted until the 7 th day of infection. Thereafter, a gradual decline of viable counts was observed.

\section{Discussion}

Jackson and Burrows (1956) and we (Wake, Morita and Yamamoto, 1972) reported similar results of in vivo studies, in which iron-administered mice were killed by 
the challenge with $\mathrm{P}^{-}$attenuated plague strains. Our interpretation of this ironeffect was that iron interfered with the defense mechanisms of the whole host animal body. On the other hand, the in vitro study of Jackson and Morris (1961), demonstrating the growth-stimulating effect of iron on several strains of Yersinia pestis, Yersinia pseudotuberculosis and Salmonella typhimurium in normal human and mouse serum, supported the interpretation of Jackson and Burrows (1956) that iron stimulates the bacterial growth also in vivo to cause deaths of the mice. The different interpretations resides in whether an increased bacterial growth at a localized site in the host does necessarily mean the lowered resistance of the whole hostmacroorganism or not. If it does, the bacteria would invade to cause generalized septicaemia as in the case of mouse-plague caused by a virulent strain. This point reminds us of the citation of Brubaker (1970) that assimilability of physiological iron in the host is the key point differentiating virulent plague strains from avirulent ones, although no conclusion was given

Concerning this discussion, however, attention must be given to the possible participation of serum-transferrin in the all of above mentioned in vivo and in vitro studies. The importance of iron-transferrin interplay in infectious diseases has been proved by a series of studies of Kochan et al. (1969 a, b, $1971 \mathrm{a}, \mathrm{b})$ on tuberculostasis in mammalian serum against Mycobacterium tuberculosis. They proved, 1) tubercle bacilli need iron for their growth, 2) serum transferrin, if not saturated with iron, takes off the iron from the bacilli, resulting in the phenomenon of tuberculostasis, and 3) tubercle bacilli exposed to an iron-poor medium multiply at a slower rate but release more serum-tuberculostasis neutralizing factor, mycobactin. Thus, iron-trasferrin complex present normally in the serum seems to correspond with one of the physiological iron mentioned above.

The plague bacilli are characterized by their shorter generation time than tubercle bacilli used by Kochan et al. That their growth in normal mammalian serum was stimulated by the addition of iron was already reported by Jackson and Morris (1961). We found that the addition of chondroitin sulfate ferric iron as much concentration as $0.5 \mathrm{mg} \mathrm{Fe} / \mathrm{ml}$ into HAPS stimulated the growth of $\mathrm{P}^{-}$avirulent strain, whereas the concentration of $0.1 \mathrm{mg} \mathrm{Fe} / \mathrm{ml}$ did not (Fig. 3). This finding may relate to the finding reported in the preceding paper (Wake, Morita and Yamamoto, 1972) that the iron drug suppressed the protective immunity afforded by the plague specific antigen, Fraction I. The amount of iron needed to neutralize the antibacterial activity of serum was thought to be of such a quantity as to provide an excess of the cation over the unbound iron-binding capacity of transferrin, an ironbinding serum protein (Weinberg, 1966). Martin, Jandl and Finland (1963) reported that the administration of human transferrin inhibited the enhancement of acute bacterial infection in rats and mice by iron. Transferrin, therefore, has been thought to constitute one of the defense mechanisms of mammalian host against bacterial infections. Kochan, Golden and Bukovic (1969 b) investigated the amount of iron present in the sera of various mammals before and after saturation with iron and the subsequent precipitation of unbound iron with magnesium carbonate. In the rabbit, an average concentration of iron of 8 samples of normal serum was $2.04 \mu \mathrm{g} /$ $\mathrm{ml}$ and after saturation with iron, it was $3.17 \mu \mathrm{g} / \mathrm{ml}$. Jackson and Morris (1961) found that $5.6 \mu \mathrm{g} \mathrm{Fe} / \mathrm{ml}$ was needed to stimulate the growth of plague strains in normal human and mouse sera. They thought this excess of iron over the maximal 
binding capacity of serum transferrin $(5.6 \mu \mathrm{g} / \mathrm{ml}-3.2 \mu \mathrm{g} / \mathrm{ml}$, here) was utilized to stimulate the growth of plague strains. In our experimental system of HAPS, it is. conceivable that the transferrin in HAPS had been rather unsaturated with iron, because Kochan, Golden and Bukovic $(1969 \mathrm{~b})$ reported that the treatments of animals. with living bacilli or lipopolysaccharide of gram-negative bacteria induce hypoferremia, and we immunized rabbit with repeated injections of a living avirulent plague strain to obtain HAPS. According to Kochan et al. (1969 b), even the maximally hypoferremic normal rabbit serum can be saturated with only $3.2 \mu \mathrm{g} / \mathrm{ml}$ of iron. In our study, however, $100 \mu \mathrm{g} \mathrm{Fe} / \mathrm{ml}$ equivalent of chondroitin sulfate ferric iron was not enough to stimulate the growth of plague microorganisms in HAPS; $500 \mu \mathrm{g} \mathrm{Fe} / \mathrm{ml}$ showed growth stimulation. Two possibilities are conceivable to explain this large diversity in the amount of iron needed for growth-stimulation. Firstly, the amount of iron-binding serum protein in the serum may have increased as a result of immunization. This possibility must be studied in the future. Secondly, the use of chondroitin sulfate ferric chloride instead of the plain iron salts may be responsible for this divergency. Laurell (1960) indicated that there is a dissociation balance between transferrin $\cdot \mathrm{Fe}$, transferrin, $\mathrm{Fe}^{3+}$, and $\mathrm{HCO}_{3}{ }^{-}$in plasma. If chondroitin sulfate ferric chloride is added to the serum, this dissociation balance may change into a new balance between transferrin $\cdot \mathrm{Fe}$, transferrin, chondroitin sulfate $\cdot \mathrm{Fe}$, chondroitin sulfate $\cdot \mathrm{Fe}^{3+}, \mathrm{Cl}^{-}$, and $\mathrm{HCO}_{3}^{-}$, because this iron drug also is a complex compound similar to the iron-saturated transferrin. It is highly possible that only $1 \%(5.6 \mu \mathrm{g}$ of $500 \mu \mathrm{g}$ added iron) is effective to stimulate the growth of plague strain in this system.

The experimental system with DBHIB added with a known amount of the iron drug is simpler than that of HAPS, because the possible dissociation balance there is between chondroitin sulfate $\cdot \mathrm{Fe}$, Chondroitin sulfate, $\mathrm{Fe}^{3+}$, and $\mathrm{Cl}^{-}$. DBHIB added with no iron drug contained less than $0.1 \mu \mathrm{g} / \mathrm{ml}$ of iron. With DBHIB as a basal medium, no significant difference in the growth of $\mathrm{EV}$ was recognized regardless of the presence or absence of the iron drug. However, the concentration more than $3 \mathrm{mg} \mathrm{Fe} / \mathrm{ml}$ remarkably inhibited the growth after the day 5 . In addition, same irregularity in the growth curve in the medium containing $0.0004 \mathrm{mg} \mathrm{Fe} / \mathrm{ml}$ $(0.4 \mu \mathrm{g} \mathrm{Fe} / \mathrm{ml})$ was observed. Because $5.6 \mu \mathrm{g} \mathrm{Fe} / \mathrm{ml}$ was needed to stimulate the growth of plague strains in the experiments of Jackson and Morris (1961), and the amount of excess iron over the unbound iron-binding capacity of preexistent transferrin in the serum used by them could be estimated to be at least $2.4 \mu \mathrm{g} / \mathrm{ml}(5.6 \mu \mathrm{g} /$ $\mathrm{ml}-3.2 \mu \mathrm{g} / \mathrm{ml}$ ), the value of $4 \mu \mathrm{g} \mathrm{Fe} / \mathrm{ml}$, over which no irregularity was observed in our experiment seems to coincide with the result of Jackson and Morris (1961). From the result obtained with solid media (DBHIA), this irregularity could be explained:

The tubes counted on the day 2 from the series containing iron-deficient broth (DBHIB, Curve 1 of Fig. 1), and containing DBHIB added with $0.0004 \mathrm{mg} \mathrm{Fe} / \mathrm{ml}$ $(0.4 \mu \mathrm{g} \mathrm{Fe} / \mathrm{ml}$ ) of the iron drug (Curve 2), had contained a few number of EV microorganisms, which could initiate the growth earlier. In the liquid medium, such microorganisms that have initiated the division are able to disperse to make the density of $\mathrm{EV}$ as high as $10^{8} / \mathrm{ml}$ within 1 day's incubation. The high value of Curve 1 on the day 3 can be explained in the same way. On the other hand, the tube from the series of Curve 2 , counted on the day 3 , had contained such micro- 
orgnaisms, which could initiate growth later than the day 2 . This series $(0.4 \mu \mathrm{g} / \mathrm{ml})$ can be regarded as virtually iron-deficient, because the lowest concentration detectable in a medium by our determination method is $0.1 \mu \mathrm{g} / \mathrm{ml}$. Any way, the presence or absence of the iron influenced only the initiation of microbial growth. It seems that, once the microorganitm have initiated to grow, later generation time is not affected irrespective of concentration of iron in the medium.

By what mechanism the iron triggers off the growth-initiation is not clear from our study. However, our experiment with DBHIA suggests the possible accumulation of some factor before the growth-initiation in some individuals of phague bacilli plated on DBHIA, like what Kochan, Pellis and Golden (1971 a) found with mycobactin. This is: the $33.0 \%$ plating efficiency of the secondly transfered substrain of EV microorganisms from the iron-deficient DBHIA onto the same DBHIA, was not explained by the selection of mutant microorganisms, requiring no iron for their growth. But, if they had succeeded in accumulating some factor which enables them to grow in the iron-poor or iron-free medium before the second transfer, it will be reasonable that the plating efficiency of the substrain $(33.0 \%)$ is the intermediate value between $100 \%$ (the expected value in the case of iron ${ }^{+}$mutant) and $1.6 \%$ (the value on the first plating on DBHIA). The formation of satellite colonies seems to be another proof of this interpretation, because the growth of one main colony seemed to induce the initiation of the growth of other many bacterial individuals which otherwise would not grow on the iron-deficient medium.

In the guinea pig skin, the direct growth-stimulating action of the drug on plague microorganisms was effective. However, this is an example showing that the bacterial multiplication alone does not necessarily mean enhanced virulence, because none of the animals died. By the intracutaneous injection of the mixture of $\mathrm{EV}$ microorganisms with high concentration $(4 \mathrm{mg} \mathrm{Fe} / \mathrm{ml})$ of chondroitin sulfate ferric chloride, a complicated dissociation balance system would be established between chondroitin sulfate $\mathrm{Fe}$, chondroitin sulfate, $\mathrm{Fe}^{3+}$, and many other substances contained in the tissue or its exsudate. A suitable amount of $\mathrm{Fe}^{3+}$ resulted from this balance system would have provided the environment available for the growth and persistence of a large number of $\mathrm{EV}$ microorganisms within these localized area of injection. As a control experiment, may serve the result described in our previous paper. The viable EV $\left(2.3 \times 10^{6} \mathrm{CFU}\right)$ suspended in saline injected subcutaneously into mice did not increase but decrease during their persistence for about 1 week (Morita, Yamamoto and Wake, 1970). When we injected $7 \times 10^{8} \mathrm{CFU}$ of $\mathrm{EV}$ suspended in $0.5 \mathrm{ml}$ saline subcutaneously into cynomolgus monkeys, only $10^{5} \mathrm{CFU}$ were recovered from the skin on the 6 th day and $10^{4} \mathrm{CFU}$ on the 8 th day (Yamamoto and Wake, unpublished data). Thus, the intracutaneous or subcutaneous injection of an attenuated plague strain together with chondroitin sulfate ferric chloride seems to ensure the in vivo multiplication.

\section{ACKNOWLEDGEMENT}

We wish to express our gratitude to Dr. Iwao Kato of the Institute for Medical Sciences, Tokyo University, for his encouraging our study and preparing the deironized medium.

\section{REFERENCES}

BRUBAKER, R. R. (1970) : Interconversion of purine mononucleotides in Pasteurella pestis, 
Infect. Immun., 1, 446-454.

JACKSON, S. AND B. C. MORRIS (1961): Enhancement of growth of Pasteurella pestis and other bacteria in serum by the addition of iron. Brit. J. Exp. Pathol., 42, 363-368.

JACKSON, S. AND T. W. BURROWS (1956): The virulence-enhancing effect of iron on nonpigmented mutants of virulent strains of Pasteurella pestis. Brit. J. Exp. Pathol., 37, 577-583.

KochAN, I. (1969a): Mechanism of tuberculostasis in mammalian serum. I. Role of transferrin in human serum tuberculostasis. J. Infect. Dis., 119, 11-18.

Kochan, I., C. A. Golden AND J. A. Bukovic (1969 b): Mechanism of tuberculostasis in mammalian serum. II. Induction of serum tuberculostasis in guinea pigs. J. Bacteriol., $100,64-70$.

Kochan, I., N. R. Pellis AND C. A. Golden (1971 a): Mechanism of tuberculostasis in mammalian serum. III. Neutralization of serum tuberculostasis by mycobactin. Infect. Immun., 3, 553-558.

Kochan, I., D. L. Cahall ANd C. A. Golden (1971 b): Employment of tuberculostasis in serum-agar medium for the study of production and activity of mycobactin. Infect. Immun., $4,130-137$.

LAURELL, C. B. (1960): Metal-binding plasma proteins and cation transport. The plasma proteins, Monograph edited by F. W. Putnam, Academic Press Inc., New York., 1, 349378.

Morita, H., M. Yamamoto AND A. WAKe (1970): Histopathological changes of mice injected with plague live vaccine strain EV. Japan. J. Med. Sci. Biol., 23, 87-97.

WAKe, A., H. MoRita AND M. Yamamoto (1972): The effect of an iron drug on host response in experimental plague infection. Japan. J. Med. Sci. Biol., 25, 75-84.

WINBERG, E. D. (1966): Roles of metallic ions in host-parasite interactions. Bacteriol. Rev., $30,136-151$. 